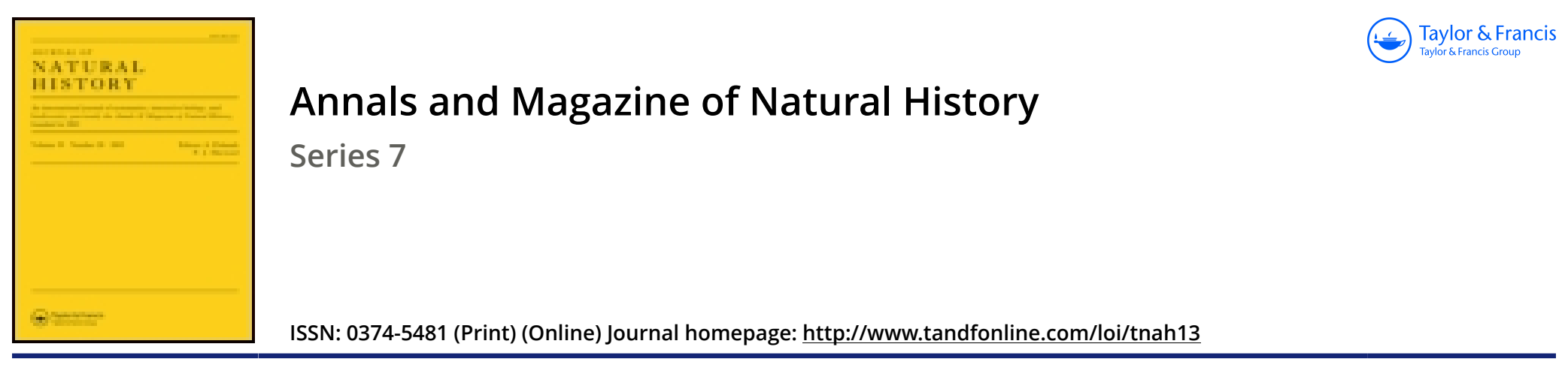

\title{
LXIV.-On a new rat of the Mus rufescens group from Simla
}

\section{J. Lewis Bonhote M.A.}

To cite this article: J. Lewis Bonhote M.A. (1903) LXIV.-On a new rat of the Mus rufescens group from Simla, Annals and Magazine of Natural History, 11:65, 473-474, DOI: 10.1080/00222930308678801

To link to this article: http://dx.doi.org/10.1080/00222930308678801

册 Published online: 29 Sep 2009.

Submit your article to this journal

Џ Article views: 3

Q View related articles $\asymp$ 
Under surface sparingly setose, the hairs longer than on the upper surface. 'The chief distinction between the sexes is that in the female the pygidium is extremely short; in the male it is twice as long.

Ootacamund (C.A.Barber, no. 205). In the collections of the British Museum, Cambridge Museum, and D. Sharp.

Cambridge,

March, 1903.

\section{LXIV.-On a new Rat of the Mus rufescens Group from Simla. By J. Lew is Bonhote, M.A.}

WHEN revising the Oriental rats of the Mus rattus group a short time ago I came across a series of eleven from Simla, differing, so far as I know, from the numerous rats of this group which have already been described. I therefore propose to describe it under the name

Mus vicerex, sp. $\mathrm{n}$.

Similar in size to typical Mus rufescens, but with shorter tail.

General colour yellowish grey, lighter on the flanks and darker on back, interspersed with long black hairs which, when seen in certain lights, have a greenish gloss. Underparts and feet white, the facial portion and top of the nose very grey. Tail of medium length, not exceeding that of the head and body, markedly bicolor and well clothed with numerous very fine hairs. Ears large and uniform dark brown in colour, having a very narrow line of white hairs round the extreme margin. Fur thickly beset with long and slender spines.

The skull resembles that of $M$. rufescens very closely; it differs, however, in the greater breadth of the nasals, with which is correlated a stouter muzzle. The audital bullæ are rather less inflated on their outer surface, giving them the appearance of lying more obliquely on the skull.

Dimensions (of type) from dried skin:- Head and body 173 millim. ; tail (tip broken) 130 ; hind foot 33 ; ear 23.

Skull: greatest length 42 millim.; basal length 34 ; palatal length 20 ; length of nasals 15 ; breadth of nasals anteriorly 4.5 ; greatest breadth of muzzle 7 ; zygomatic breadth, approx., 21 ; greatest breadth of brain-case 16 .

$H a b$. Simla. 
Type. B.M. no. 85. 8. 1. 313 . Adult female, 25th October, 1877, collected and presented by Mr. A. O. Hume.

Although closely allied to Mus rufescens the short bicolor tail clothed with fine hairs forms an unmistakable character by which it may always be easily recognized. Although the majority of the series are of a very uniform pale colour, several specimens show a tendency to become more rufous, but in no case do they become nearly so bright as in Mus rufescens. The narrow white edging to the ear is also a well-marked feature. Externally and at first sight this species bears a considerable resemblance to Mus Blanfordi, but the presence of spines in the fur, which are entirely absent in $M$. Blanfordi, as well as the pure white terminal portion of the tail of the last-named prevent any risk of confusion. The skulls of the two species are not closely alike.

The average length of tail in the series of eleven specimens is 158 millim. (145-170); the tail of the type is slightly broken at the tip.

\section{LXV.-On Two new Species of Cat from China.} By J. Lewis Bonhote, M.A.

THE Museum has just received from Mr. Henry Brelich the skin of a small cat from the province of Kweichow, which is so distinct from the cats hitherto recorded from China that I have no hesitation in describing it as new, and propose for it the name

\section{Felis Ingrami, sp. n.}

Size very small, and tail less than half the length of the body. General colour pale buff, shading to white on the underparts. Body thickly covered with dark markings of irregular shape, showing espocially on the sides a tendency to form rosettes, the centre of the spot being of a warm rufous brown. Along the median dorsal area the markings become linear and form two broken lines the whole length of the body, the ground-colour in this area being similar to that in the centre of the spots. The limbs are spotted in a similar manner to the body right down to the toes. On the underparts the spots are pure black, without any of the rufous hairs. The head above the cheeks is of the same groundcolour as the rest of the body, and from above the eyes four narrow clear-cut black stripes run backwards as far as the shoulders, where they lose themselves in a transverse rufous 